\title{
Isolation and characterization of turkey prolactin
}

\author{
K. W. Cheng and R. J. Etches* \\ Department of Physiology, Faculty of Medicine, University of Manitoba, Winnipeg, Manitoba \\ R3E OW3 and *Department of Animal and Poultry Science, University of Guelph, Guelph, \\ Ontario NIG 2WI, Canada
}

\begin{abstract}
Summary. Prolactin from frozen turkey pituitary glands was purified by alkaline ethanol extraction of the pituitary residue after pre-extractions of the gonadotrophins and GH, followed by gel filtration on Sephadex G-100 and DEAE-cellulose column chromatography at different $\mathrm{pH}$. A specific radioligand-receptor assay for ovine prolactin was used to locate the activity in eluates after column chromatography and gel filtration. The potency of the highly purified turkey prolactin was characterized by a radioligand-receptor assay to be $3.40 \mathrm{i} . \mathrm{u} . / \mathrm{mg}$ and by a heterologous radioimmunoassay to be 35 i.u./mg as compared to purified ovine prolactin as standard. The yield of turkey prolactin was $3 \mathrm{mg} / 100 \mathrm{~g}$ frozen pituitary glands. The purified turkey prolactin consisted of three protein bands upon polyacrylamide gel electrophoresis and the molecular weight was estimated to be 22000 by SDS-polyacrylamide gel electrophoresis. Turkey prolactin was rich in aspartic acid, glutamic acid and leucine, but lacking in methionine.
\end{abstract}

\section{Introduction}

Comparative studies on the endocrinology of pituitary prolactin requires the availability of the purified hormone to characterize its chemical nature and physiological actions within and between species. Mammalian prolactin has been purified from pituitary glands of various species, including the cow (Jiang \& Wilhelmi, 1965), pig (Kwa, Van der Bent, Feltkamp, Runke \& Bloemendal, 1965), goat (McNeilly \& Andrews, 1974), rat (Ellis, Grindeland, Neunke \& Callahan, 1969; Gala, 1972) and man (Lewis, Singh \& Seavey, 1971; Hwang, Guyda \& Friesen, 1972). The purification of chicken prolactin has also been reported (Scanes, Bolton \& Chadwick, 1975 ) and since the current isolation of turkey prolactin was initiated, Burke \& Papkoff (1980) have described the purification of turkey prolactin. The present paper describes our procedure to obtain highly purified turkey prolactin and some biological and chemical properties of the purified hormone, since these appear to differ in some respects from those of the preparation purified by Burke \& Papkoff (1980).

\section{Materials and Methods}

Materials. Ovine prolactin (NIH-P-S12) and bovine growth hormone (GH) (NIH-GH-B18) were obtained from the NIAMDD, National Institutes of Health, Bethesda, Maryland, U.S.A. Bovine TSH (potency 30-40 i.u./mg) and bovine LH (potency 2.0 $\times$ NIH-LH-S1) were gifts from Dr J. G. Pierce, UCLA, California. Bovine FSH (potency $160 \times$ NIH-FSH-S1) was prepared as described previously (Cheng, 1976). DEAE-cellulose (Whatman DE-32) was purchased from H. Reeve Angel Inc., Clifton, New Jersey, U.S.A. Sephadex G-100 was from 
Pharmacia (Canada) Ltd, Dorval, Quebec; and Ultrogel AcA 44 was from LKB-Produkter AB, Stockholm, Sweden. Bovine serum albumin (fraction V) was purchased from Miles Laboratory, Kankakee, Illinois, U.S.A. Ovalbumin, chymotrypsinogen A, myoglobin and cytochrome C were obtained from Sigma Chemical Co., St Louis, Missouri, U.S.A. Na ${ }^{125}$ I (carrier-free) was from New England Nuclear, Boston, Massachusetts, U.S.A. Lactoperoxidase was from Calbiochem, LaJolla, California, U.S.A. $\mathrm{H}_{2} \mathrm{O}_{2}(30 \% \mathrm{v} / \mathrm{v})$ was obtained from Fisher Scientific, Fair Lawn, New Jersey, U.S.A. All other reagents and chemicals were reagent grade.

Protein determination. The distribution of proteins in eluates after fractionation on ion-exchange column chromatography and gel filtration on Sephadex G-100 or Ultrogel AcA 44 was monitored spectrophotometrically by absorbance at $278 \mathrm{~nm}$.

Radioligand-receptor assay for prolactin. The distribution of prolactin activity in eluates after fractionation on column chromatography was determined by a sensitive and specific radioligand-receptor assay (Shiu, Kelly \& Friesen, 1973) using particulate plasma membranes $(0.5-1.5 \mathrm{mg}$ protein $/ \mathrm{ml})$ from pregnant rabbit mammary glands as receptor. Purified ovine prolactin (NIH-P-S 12; potency 35 i.u. $/ \mathrm{mg}$ ) was used as standard and the ${ }^{125}$ I-labelled hormone $(40-60 \mu \mathrm{Ci} / \mu \mathrm{g})$ as tracer. The sensitivity was $1-2 \mathrm{ng} / \mathrm{ml}$ and the precision of the assay was $10 \%$ within assays and $15 \%$ between assays as expressed by the coefficient of variation.

Extraction of pituitary prolactin. The turkey pituitary glands were processed in batches from freshly frozen heads of slaughterhouse birds (Cuddy Farms Ltd, Strathroy, and Canada Parchers Ltd, Walkerton, Ontario, Canada). The frozen glands were stored at $-20^{\circ} \mathrm{C}$ for $2-6$ months before being thawed, washed with several volumes of ice-cold $0.9 \%(\mathrm{w} / \mathrm{v}) \mathrm{NaCl}$ and homogenized at a concentration of $10 \mathrm{ml}$ ice-cold water $/ \mathrm{g}$ tissue. The glycoprotein hormones and $\mathrm{GH}$ were extracted serially at $4^{\circ} \mathrm{C}$, in aqueous solution at $\mathrm{pH} 5 \cdot 5$, followed by $0 \cdot 1 \mathrm{M}$-ammonium sulphate, $\mathrm{pH} 4 \cdot 0$, and $0.25 \mathrm{M}$-ammonium sulphate, $\mathrm{pH} 5 \cdot 5$, according to the procedure of Ellis (1961). The pituitary residue was then extracted for prolactin by the method of Jiang \& Wilhelmi (1965) with $30 \mathrm{~mm}-\mathrm{NaOH}$ in $75 \%$ ethanol at a concentration of $5 \mathrm{ml} / \mathrm{g}$ original tissue at $4^{\circ} \mathrm{C}$ for $2 \mathrm{~h}$. After centrifugation the supernatant was adjusted to $\mathrm{pH} 5 \cdot 5$ with $0 \cdot 1 \mathrm{~N}-\mathrm{HCl}$. Two volumes of ethanol were added and left overnight at $4^{\circ} \mathrm{C}$ for full precipitation of prolactin. The prolactin fraction was collected by centrifugation, resuspended in $0.5 \% \mathrm{NH}_{4} \mathrm{HCO}_{3}$, dialysed against water and then freeze dried.

Gel filtration on Sephadex G-100. The crude turkey prolactin fraction was dissolved in $0.5 \%$ $\mathrm{NH}_{4} \mathrm{HCO}_{3}$, adjusted to $\mathrm{pH} 9.5$ with $0.1 \mathrm{~N}-\mathrm{NaOH}$ and subjected to gel filtration on Sephadex G-100. To locate the activity the eluates were assayed by a radioligand-receptor assay for ovine prolactin and the appropriate fractions were pooled and freeze dried.

$D E A E$-cellulose column chromatography. The freeze-dried material was dissolved in the respective initial equilibrating buffer at a concentration of $10 \mathrm{mg} / \mathrm{ml}$, and the $\mathrm{pH}$ of the solution was re-adjusted with $0.1 \mathrm{~N}-\mathrm{NaOH}$ or $\mathrm{HCl}$. The prolactin activity was first separated from most contaminating proteins by DEAE-cellulose chromatography at $\mathrm{pH} 9 \cdot 5$. The ion-exchanger was equilibrated in $5 \mathrm{~mm}$-sodium glycinate, $\mathrm{pH} \mathrm{9.5,} \mathrm{and} \mathrm{was} \mathrm{eluted} \mathrm{by} \mathrm{a} \mathrm{stepwise} \mathrm{gradient} \mathrm{of}$ increasing concentrations of sodium glycinate at the same $\mathrm{pH}$. The active fractions were pooled, dialysed and freeze dried. Prolactin was further purified by a DEAE-cellulose column in 0.01 M-Tris- $\mathrm{HCl}$ buffer, $\mathrm{pH} 7.25$, and was eluted by generating a continuous gradient of $\mathrm{NaCl}$ in the same buffer. The active fractions were pooled, dialysed and freeze dried. The prolactin activity was further fractionated from other minor contaminant proteins by DEAE-cellulose chromatography at $\mathrm{pH} 8 \cdot 25$. The appropriate fractions of prolactin were pooled, dialysed and freeze dried.

Gel filtration on Ultrogel $A C A-44$. Turkey prolactin was finally purified by gel filtration on Ultrogel AcA-44. The appropriate fractions of prolactin were again located by a radioligandreceptor assay, pooled and freeze dried.

Heterologous radioimmunoassay for turkey prolactin. The potency of the purified turkey prolactin was estimated by the heterologous radioimmunoassay reported by McNeilly, Etches \& Friesen (1978). This method used a guinea-pig antiserum (AGP-4) against human prolactin and 
an ${ }^{125}$ I-labelled ovine prolactin (NIH-PRL-S12) tracer, and was expressed in terms of ovine prolactin (NIH-PRL-S12). The intra- and inter-assay coefficients of variation of this method were 8.9 and $13.7 \%$, respectively; and the sensitivity of the assay was approximately $1 \mathrm{ng} / \mathrm{ml}$.

Specific binding of ${ }^{125} \mathrm{I}$-labelled turkey prolactin to particulate receptors. Turkey prolactin was labelled with $0.5 \mathrm{mCi}^{125} \mathrm{I} / 2 \mu \mathrm{g}$ hormone by the enzymic method with lactoperoxidase as described previously (Cheng, 1975) with minor modifications. Particulate receptors from pregnant rabbit mammary glands were prepared according to the procedure of Shiu et al. (1973). The specific binding of the ${ }^{125}$ I-labelled turkey and ovine prolactin (sp. act. 38 and $52 \mu \mathrm{Ci} / \mu \mathrm{g}$, respectively) was studied individually by incubating $0.1 \mathrm{ml}$ labelled hormone (50 000 c.p.m.) with $0.1 \mathrm{ml} \mathrm{re-suspended} \mathrm{particulate} \mathrm{receptors}(6 \mathrm{mg}$ protein $/ \mathrm{ml})$ in the absence or presence of excess unlabelled ovine prolactin $(1 \mu \mathrm{g} /$ tube $)$ at a final volume of $0.5 \mathrm{ml} 5 \mathrm{~mm}$-Tris- $\mathrm{HCl}, \mathrm{pH} 7.4$, containing $0.1 \% \mathrm{BSA}$ and $10 \mathrm{mM} \mathrm{MgCl}_{2}$ according to Cheng (1976). The incubation was carried out at $23^{\circ} \mathrm{C}$ for $16 \mathrm{~h}$. Free and bound ${ }^{125} \mathrm{I}$-labelled hormones were separated by centrifugation ( $2000 \mathrm{~g}$ for $30 \mathrm{~min}$ at $4^{\circ} \mathrm{C}$ ) and the pellet was counted in an automatic gamma spectrometer.

Polyacrylamide-gel electrophoresis. Polyacrylamide-gel electrophoresis was carried out by the method of Davis (1964) and $7.5(\mathrm{w} / \mathrm{v})$ acrylamide gel was used. Electrophoresis on $10 \%$ $(\mathrm{w} / \mathrm{v})$ polyacrylamide gel with sodium dodecyl sulphate (SDS) was carried out according to Weber \& Osborn (1969). The protein markers for estimation of molecular weight were serum albumin (68 000), ovalbumin (45 000), chymotrypsinogen A (25000), myoglobin (17 800) and cytochrome C (12 400). The gels were stained for proteins with $1 \%$ Amido Black $10 \mathrm{~B}$ solution in $7 \%$ acetic acid.

Amino acid analysis. Purified turkey prolactin was hydrolysed with $6 \mathrm{~N}-\mathrm{HCl}$ in evacuated, sealed tubes at $110^{\circ} \mathrm{C}$ for $22 \mathrm{~h}$ and the amino acid composition was analysed with an automatic amino acid analyser.

\section{Results}

\section{Procedure for the purification of turkey prolactin}

Data relating to the various purification steps are shown in Table 1. A substantial amount of the crude extract was insoluble in water or $0.5 \% \mathrm{NH}_{4} \mathrm{HCO}_{3}$, and became dissolved only after adjustments of the $\mathrm{pH}$ to $>\mathrm{pH} 9 \cdot 0$. After the various purification steps (Text-fig. 1a-e) the final yield was $3 \mathrm{mg}$ turkey prolactin/100 $\mathrm{g}$ frozen pituitary glands.

Table 1. Recovery of prolactin at different steps of purification ( $50 \mathrm{~g}$ batch)

\begin{tabular}{lccccc}
\hline Fraction & $\begin{array}{c}\text { Yield of } \\
\text { protein } \\
(\mathrm{mg})\end{array}$ & $\begin{array}{c}\text { Relative } \\
\text { potency } \\
(\mu \mathrm{g} / \mathrm{mg})\end{array}$ & $\begin{array}{c}\text { Activity } \\
(\mu \mathrm{g})\end{array}$ & $\begin{array}{c}\text { Recovery } \\
(\%)\end{array}$ & Text-fig. 1 \\
\hline Alkaline ethanol extract & 82.1 & 12.0 & 985.2 & 100 & \\
Sephadex G-100 & 21.6 & 31.0 & 669.6 & 68.0 & (a) \\
DEAE-cellulose, pH 9.50 & 8.9 & 45.5 & 405.9 & 41.2 & $(\mathrm{~b})$ \\
DEAE-cellulose, pH 7.25 & 4.8 & 51.6 & 247.7 & 25.1 & (c) \\
DEAE-cellulose, pH 8.25 & 2.8 & 77.3 & 216.4 & 21.9 & (d) \\
Ultrogel AcA-44 & 1.5 & 97.2 & 145.8 & 14.8 & (e) \\
\hline
\end{tabular}

\section{Characterization of biological properties}

The turkey prolactin preparation was assessed for contamination of pituitary protein and glycoprotein hormones by various radioligand-receptor assays: pregnant rabbit liver receptors for growth hormone (Tsushima \& Friesen, 1973), bovine testicular receptors for FSH (Cheng, 1975), bovine CL receptors for $\mathrm{LH}$ (Cheng, 1976) and porcine thyroid receptors for TSH 


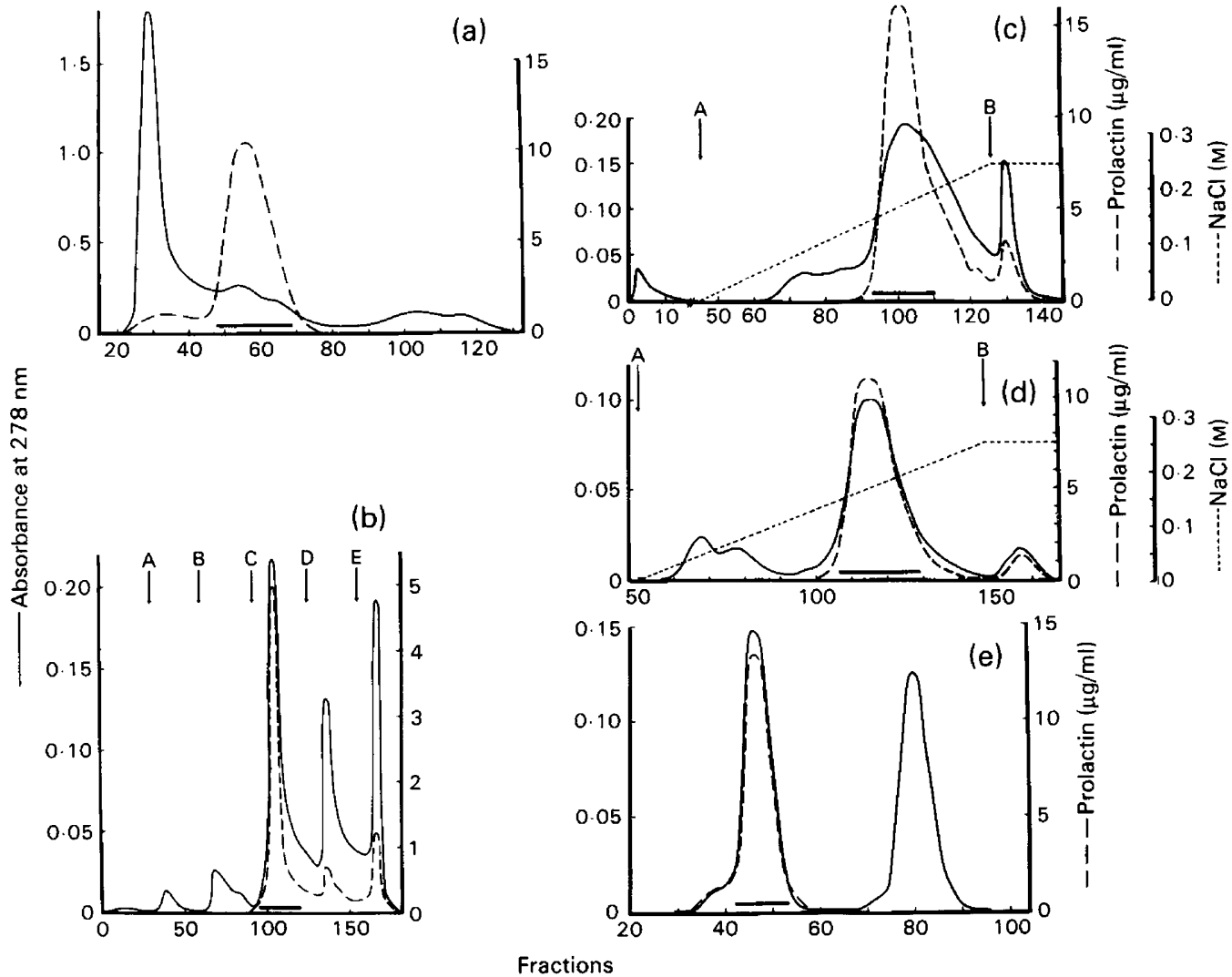

Text-fig. 1. The various separation steps in the purification of turkey prolactin (see 'Materials and Methods' and Table 1). The absorbance at each stage (-) was measured at $278 \mathrm{~mm}$ $\left(E_{278}\right)$. The prolactin fractions were monitored by radioligand-receptor assay and pooled as indicated by the horizontal bars. (a) Gel filtration of crude alkaline ethanol extract of turkey pituitaries on Sephadex G-100 in $0.5 \% \mathrm{NH}_{4} \mathrm{HCO}_{3}$. The crude extract $(82.1 \mathrm{mg})$ was dissolved in $5 \mathrm{ml}$ buffer and applied to the column $(2.5 \times 90 \mathrm{~cm})$. Fractions $(4.5 \mathrm{ml})$ were collected at a flow rate of $25 \mathrm{ml} / \mathrm{h}(---)$. (b) Chromatography of the prolactin fraction of (a) on a DEAE-cellulose column $(1.4 \times 6 \mathrm{~cm})$ in $5 \mathrm{~mm}$-sodium glycinate buffer, $\mathrm{pH} 9.5$. The material $(21.6 \mathrm{mg}$ ) was dissolved in $5 \mathrm{ml}$ buffer, dialysed overnight and applied to the column. A stepwise elution with $0 \cdot 1,0.2,0.5$ and $1 \mathrm{M}$-sodium glycinate at $\mathrm{pH} 9.5$ and finally $1 \mathrm{M}$-ammonium acetate was used as indicated by the arrows $\mathrm{A}, \mathrm{B}, \mathrm{C}, \mathrm{D}$ and $\mathrm{E}$ to fractionate the proteins (---). Fractions $(3 \mathrm{ml})$ were collected. (c) Chromatography of the prolactin fraction of (b) on a DEAE column $(1 \times 8 \mathrm{~cm})$ in $10 \mathrm{~mm}$-Tris- $\mathrm{HCl}, \mathrm{pH} 7.25$. The material $(8.9 \mathrm{mg})$ was dissolved in $2 \mathrm{ml}$ buffer, dialysed and applied to the column. After elution of the unadsorbed material with 10 mM-Tris- $\mathrm{HCl}$, a linear gradient of $0-0.25 \mathrm{M}-\mathrm{NaCl}$ in the same buffer was applied as indicated by arrow $\mathrm{A}$, and the elution was finished by applying more $0.25 \mathrm{M}-\mathrm{NaCl}$ buffer (arrow B). Fractions $(1 \mathrm{ml})$ were collected. (d) Chromatography of the prolactin fraction of (c) $(4.8 \mathrm{mg})$ on a DEAE-cellulose $(0.6 \times 8 \mathrm{~cm})$ in $10 \mathrm{~mm}$-Tris- $\mathrm{HCl}$, pH 8.25. (e) Gel filtration of the prolactin fraction of (d) on Ultrogel AcA-44 $(1 \times 110 \mathrm{~cm})$ in $0.5 \% \mathrm{NH}_{4} \mathrm{HCO}_{3}$. The material $(2.8 \mathrm{mg})$ was dissolved in $0.5 \mathrm{ml}$ buffer and applied to the column. The fractions collected were $1 \mathrm{ml}$ and the pooled material was $1.5 \mathrm{mg}$.

(Workewych \& Cheng, 1978). By these radioligand-receptor assays for mammalian hormones, the purified turkey prolactin was practically free $(<0.01 \%)$ from any of these hormone activities at concentrations of $10 \mu \mathrm{g} / \mathrm{ml}$. Contamination of $\mathrm{LH}$ activity was further assessed by the bioassay using dispersed testicular cells as described by Maung \& Follett (1977). No response was observed for turkey prolactin at concentrations of $100 \mathrm{ng} / \mathrm{ml}$. 
By a radioligand-receptor assay for ovine prolactin, the purified turkey prolactin was estimated to possess only $0.097 \times$ the potency of ovine prolactin (NIH-P-S12; potency 35 i.u./mg), i.e. 3.40 i.u./mg. The slopes of the dose-response curves of both turkey and ovine prolactin were almost identical (Text-fig. 2). The difference in degree of inhibition is probably due to species differences in the interactions with the receptor molecule. The specific binding of ${ }^{125}$ I-labelled turkey prolactin to rabbit mammary receptors was $11.8 \%$ as compared to $25 \cdot 2 \%$ for ${ }^{125}$ I-labelled ovine prolactin; thus, a substantial amount of binding was observed for the avian hormone to the receptor from a mammalian source.

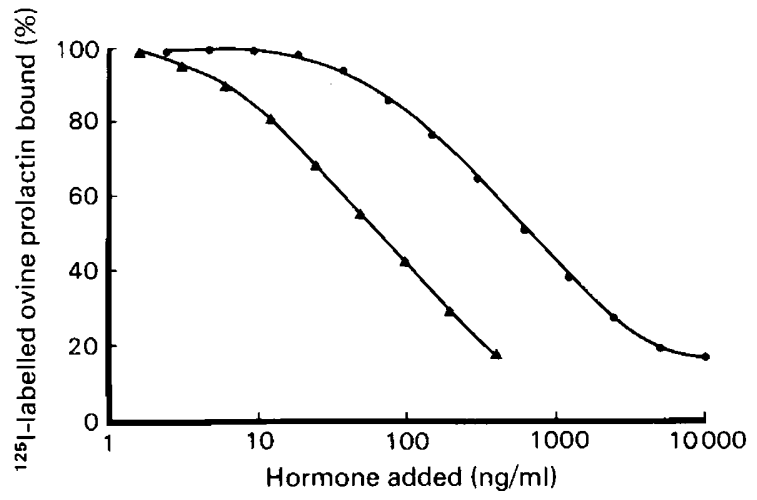

Text-fig. 2. Dose-response curves of purified turkey prolactin (๑) and ovine prolactin (NIH-P-S12) (A) in a radioligand-receptor assay, using ${ }^{125}$ I-labelled ovine prolactin as tracer and particulate receptors from rabbit mammary glands. Each point represents the mean of duplicate estimates in two assays.

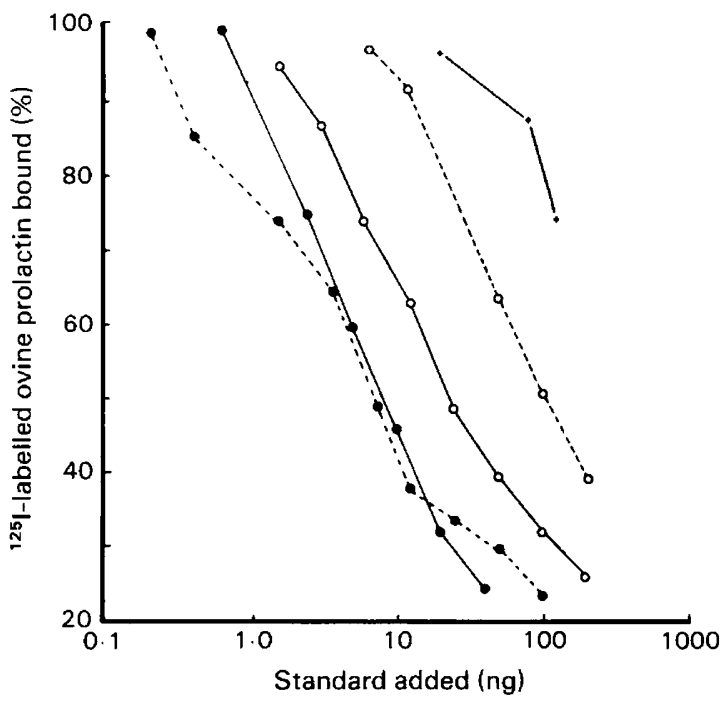

Text-fig. 3. Dose-response curves of ovine prolactin (NIH-P-S12) ), semi-purified turkey prolactins HS-1 (O---O) and Ultro II $(\mathrm{O}-\mathrm{O})$, and purified turkey prolactin HS-1-139 (--- ), and turkey growth hormone W130CD $(+-++)$, using ${ }^{125}$ I-labelled ovine prolactin as tracer and a guinea-pig anti-human prolactin serum. Each point represents the mean of duplicate estimates in 2 assays. 
Using the heterologous radioimmunoassay for avian prolactin described by McNeilly et al. (1978), the potency of purified turkey prolactin (HS-1-139) was equal to or slightly greater than that of ovine prolactin (NIH-P-S12) (Text-fig. 3). Two other semi-purified preparations of turkey prolactin, identified as HS-1 and Ultro II, possessed 6.3 and $27 \cdot 1 \%$, respectively, of the immunological activity of ovine prolactin (Text-fig. 3). The dose-response curve of each of these preparations was parallel to that of the ovine prolactin standard, indicating that the preparations were immunologically similar to ovine prolactin. In this assay the turkey growth hormone W130 DB, which was described by Farmer, Papkoff \& Hayashida (1974), has $<3 \cdot 1 \%$ of the immunoactivity of ovine prolactin (Text-fig. 3). McNeilly et al. (1978) reported that the GH preparation W 27 CD possessed $<0.01 \%$ of the inhibitory activity of ovine prolactin NIH-P-S 10 .

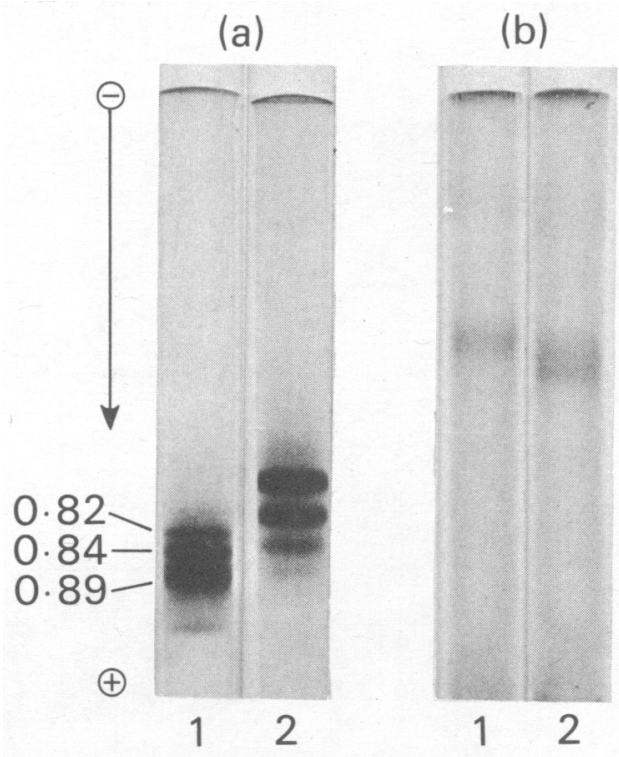

Text-fig. 4. Polyacrylamide-gel electrophoresis at $\mathrm{pH} 8.9$ (a), and in the presence of sodium dodecyl sulphate (b) of pituitary turkey prolactin (sample 1) and ovine prolactin (sample 2). The $R_{\mathrm{F}}$ values are shown.

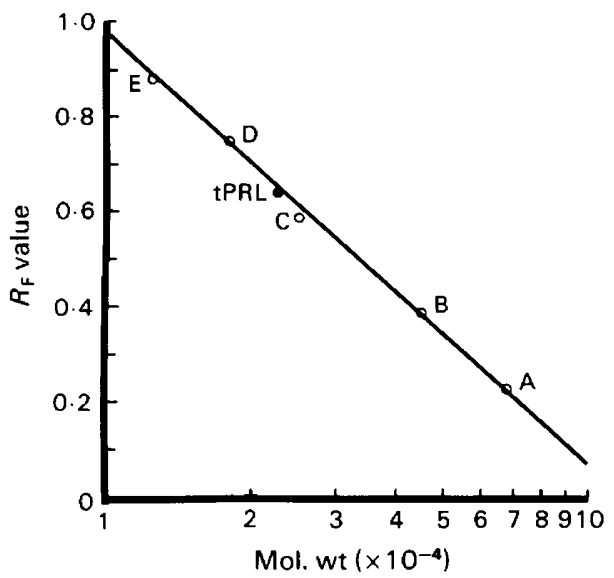

Text-fig. 5. Estimation of molecular weight by SDS/gel electrophoresis. The $R_{\mathrm{F}}$ values of the proteins are plotted against their molecular weights on a logarithmic scale. $\mathrm{A}=$ bovine serum albumin; $\mathrm{B}=$ ovalbumin; $\mathrm{C}=$ chymotrypsinogen $\mathrm{A} ; \mathrm{D}=$ myoglobin; $\mathrm{E}=$ cytochrome $\mathrm{C}$; $\mathrm{tPRL}=$ turkey prolactin 


\section{Characterization of chemical properties}

Electrophoretically, purified turkey prolactin consisted of approximately three protein bands having $R_{\mathrm{F}}$ values of $0.82,0.84$ and 0.89 which migrated slightly further towards the anode as compared to the protein bands of ovine prolactin (Text-fig. 4a). However, after SDS-gel electrophoresis, both turkey and ovine prolactin gave single protein bands of relatively similar mobilities (Text-fig. 4b). The molecular weight of purified turkey prolactin was estimated to be 22000 (Text-fig. 5).

The amino acid composition of turkey prolactin was relatively similar to that of ovine prolactin, being rich in aspartic acid, glutamic acid, and leucine (Table 2). Apart from the virtual absence of methionine in our preparation the amino acid composition was similar to that reported by Burke \& Papkoff (1980).

Table 2. Comparison of amino acid composition of turkey prolactin with chicken and ovine prolactin

\begin{tabular}{|c|c|c|c|c|c|}
\hline \multirow[b]{2}{*}{ Amino acid } & \multicolumn{2}{|c|}{ Turkey prolactin } & \multirow{2}{*}{$\begin{array}{l}\text { Chicken } \\
\text { prolactin } \\
\text { (Scanes et } \\
\text { al., 1975) }\end{array}$} & \multirow{2}{*}{$\begin{array}{c}\text { Ovine } \\
\text { prolactin } \\
\text { (Sluyer \& } \\
\mathrm{Li}, 1964 \text { ) }\end{array}$} & \multirow{2}{*}{$\begin{array}{c}\text { Turkey } \\
\text { GH } \\
\text { (Farmer et } \\
\text { al., 1974) }\end{array}$} \\
\hline & $\begin{array}{l}\text { Present } \\
\text { study }\end{array}$ & $\begin{array}{c}\text { Burke \& } \\
\text { Papkoff }(1980)\end{array}$ & & & \\
\hline Lysine & $5 \cdot 37$ & 5.57 & 6.9 & $4 \cdot 5$ & 6.9 \\
\hline Histidine & $4 \cdot 35$ & $3 \cdot 29$ & $2 \cdot 7$ & $4 \cdot 0$ & $2 \cdot 2$ \\
\hline Arginine & $5 \cdot 70$ & $5 \cdot 12$ & $4 \cdot 8$ & 5.6 & $4 \cdot 4$ \\
\hline Aspartic acid & 11.99 & $11 \cdot 14$ & $12 \cdot 5$ & $11 \cdot 0$ & $10 \cdot 7$ \\
\hline Threonine & 3.31 & 3.55 & $3 \cdot 5$ & 4.6 & $5 \cdot 2$ \\
\hline Serine & $7 \cdot 14$ & $7 \cdot 14$ & 9.7 & $8 \cdot 1$ & $6 \cdot 2$ \\
\hline Glutamic acid & 14.00 & $17 \cdot 07$ & $16 \cdot 7$ & $11 \cdot 1$ & $14 \cdot 6$ \\
\hline Proline & $3 \cdot 30$ & 4.91 & $4 \cdot 5$ & $5 \cdot 6$ & 6.0 \\
\hline Glycine & 6.90 & $7 \cdot 24$ & $10 \cdot 2$ & 5.6 & 6.9 \\
\hline Alanine & 5.72 & 6.68 & 8.9 & 4.5 & $7 \cdot 3$ \\
\hline$\frac{1}{2}$ Cystine & $1 \cdot 30^{*}$ & 2.08 & ND & $3 \cdot 0$ & $2 \cdot 2$ \\
\hline Valine & $5 \cdot 14$ & $4 \cdot 10$ & $4 \cdot 7$ & $5 \cdot 1$ & 5.5 \\
\hline Methionine & 0.08 & 1.57 & ND & $3 \cdot 5$ & 1.9 \\
\hline Isoleucine & $6 \cdot 33$ & $4 \cdot 31$ & 3.5 & $5 \cdot 6$ & 3.6 \\
\hline Leucine & $13 \cdot 35$ & $10 \cdot 38$ & $7 \cdot 9$ & $10 \cdot 6$ & $10 \cdot 0$ \\
\hline Tyrosine & $2 \cdot 10$ & 2.33 & 1.8 & $3 \cdot 5$ & 2.8 \\
\hline Phenylalanine & 4.00 & 3.49 & $2 \cdot 5$ & $3 \cdot 0$ & 3.7 \\
\hline Tryptophane & ND & 1.01 & ND & & \\
\hline
\end{tabular}

Values are expressed as residues per 100 residues of amino acid. ${ }^{*}=$ no special measure has been applied for the instability of this amino acid during hydrolysis; ND $=$ not determined.

\section{Discussion}

The procedure of serial extractions of the pituitary gland (Ellis, 1961) was very useful as the initial step for the fractionation of gonadotrophins, $\mathrm{GH}$ and prolactin. The first step of gel filtration on Sephadex G-100 separated out a large amount of contaminating proteins and permitted better fractionation by subsequent ion-exchange chromatography. A specific radioligand-receptor assay is also essential to obtain highly purified prolactin for monitoring the distribution of activity in eluates after continuous gradient ion-exchange column chromatography. Although prolactin activity was found in the major protein peak, the distribution of activity was not exactly identical with that of the proteins.

The application of a mammalian radioreceptor assay to monitor the purity of the preparations during the purification of the non-mammalian prolactin is a novel approach although it was suggested previously by Prunet, Djiane \& Breton (1977). It is still debatable whether or not radioreceptor assays are an index of biological activity although Forsyth, Buntin 
\& Nicoll (1978) reported a correlation of 0.93 between the pigeon crop-sac bioassay and a pigeon crop sac radioreceptor assay. The dissociation constants and binding capacity of the pigeon crop-sac receptors were very similar to those of the rabbit mammary gland receptors which were used in the present purifications. The biological activity of turkey prolactin preparations would be judged most effectively in a turkey bioassay or radioreceptor assay but these are currently unavailable since the target organ for prolactin in this species is still unknown. It is therefore apparent that heterologous bioassays, immunoassays and/or radioreceptor assays must be used in the initial investigations.

The biological potency of the purified turkey prolactin was much lower than the potency of the ovine prolactin in the radioreceptor assay. Nevertheless, there was a substantial amount of specific binding of ${ }^{125}$ I-labelled turkey prolactin with particulate receptors from mammary glands of pregnant rabbits. These results are similar to those derived when avian gonadotrophins are reacted with mammalian receptors (Licht \& Midgley, 1976; Jenkins, Sumpter \& Follett, 1978). Similarly, purified avian gonadotrophins have shown very little biological activity when tested in mammalian bioassays (Stockell-Hartree \& Cunningham, 1969; Scanes \& Follett, 1972). In addition, the chicken prolactin purified by Scanes et al. (1975) was usually less potent than the ovine standard in the pigeon crop-sac bioassay, in spite of the relatively close phylogenetic relationship between chickens and pigeons. Similarly, the turkey prolactin isolated by Burke \& Papkoff (1980) was less potent than ovine prolactin in the pigeon crop-sac bioassay and the dose-response curves of the ovine and turkey prolactin were not parallel. These results emphasize the inherent difficulties in selecting an appropriate measure of biological activity of the purified preparations and the need for further investigations of the relationship between biological and receptor-binding activities.

Both turkey and ovine prolactins showed heterogeneity of 3-4 protein bands after polyacrylamide gel electrophoresis at an alkaline $\mathrm{pH}$. The $R_{\mathrm{F}}$ values of these proteins were comparable to those reported by Burke \& Papkoff (1980) for turkey prolactin, and Nicoll \& Nichols (1971) for prolactin activity (by pigeon crop-sac assay) in chicken pituitary extracts. After polyacrylamide-SDS gel electrophoresis a homogeneous band of molecular weight 22000 was obtained for our preparation of turkey prolactin. Burke \& Papkoff (1980) reported a molecular weight of 26000 . In general, the amino acid compositions of avian and mammalian gonadotrophins (Farmer, Papkoff \& Licht, 1975; Godden \& Scanes, 1975) and GH (Farmer et al., 1974) show remarkable similarity. The amino acid composition of our turkey prolactin, apart from the lack of methionine, was relatively similar to those reported for chicken prolactin and turkey prolactin, being rich in aspartic acid, glutamic acid and leucine.

The development of an homologous radioimmunoassay is essential for physiological studies to determine the biological role of prolactin in avian species. The availability of a highly purified turkey prolactin will facilitate such investigations.

This research was supported by M.R.C. (Canada) Grant MA-6080 and K.W.C. is an M.R.C. Scholar. We thank Cheryl Duke, Herminia Sy and Glenda Lagadi for technical assistance; Janet Greer for typing the manuscript; Dr J. Proudman, USDA, for the gift of turkey growth hormone; and the NIAMDD, NIH for the supply of other pituitary hormone preparations.

\section{References}

Burke, W.H. \& Papkoff, H. (1980) Purification of turkey prolactin and the development of a homologous radioimmunoassay for its measurement. Gen. Comp. Endocr. 40, 297-307.
Cheng, K.W. (1975) A radioreceptor assay for folliclestimulating hormone. J. Clin. Endocr. Metab. 41, 581-589.

Cheng, K.W. (1976) Carboxymethylation of methionine Downloaded from Bioscientifica.com at 04/25/2023 11:17:27PM 
residues in bovine pituitary luteinizing hormone and its subunit. Effects on the binding activity with receptor sites and interactions between subunit. Biochem. J. 159, 71-77.

Davis, B.J. (1964) Disc electrophoresis. II. Method and application to serum proteins. Ann. N.Y. Acad. Sci. 121, $404-427$.

Ellis, S. (1961) Studies on the serial extraction of proteins. Endocrinology 69, 554-570.

Ellis, S., Grindeland, R.E., Neunke, J.M. \& Callahan, P.X. (1969) Purification and properties of rat prolactin. Endocrinology 85, 886-894.

Farmer, S.W., Papkoff, H. \& Hayashida, T. (1974) Purification and properties of avian growth hormones. Endocrinology 95, 1560-1565.

Farmer, S.W., Papkoff, H. \& Licht, P. (1975) Purification of turkey gonadotropins. Biol. Reprod. 12, $415-422$.

Forsyth, I.A., Buntin, J.D. \& Nicoll, C.S. (1978) Pigeon crop-sac radioreceptor assay for prolactin. J. Endocr. 79, 349-356.

Gala, R. (1972) Studies on the purification of rat prolactin from anterior pituitary organ culture by preparative disc electrophoresis. Hormones 3, 343353.

Godden, P.M.M. \& Scanes, C.G. (1975) Studies on the purification and properties of avian gonadotropins. Gen. comp. Endocr. 27, 538-542.

Hwang, P., Guyda, H. \& Friesen, H. (1972) Purification of human prolactin. J. biol. Chem. 247, 1955-1958.

Jenkins, N., Sumpter, J.P. \& Follett, B.K. (1978) The effects of vertebrate gonadotropins on androgen release in vitro from testicular cells of Japanese Quail and a comparison of their radioimmunoassay activities. Gen. comp. Endocr. 35, 309-322.

Jiang, N.S. \& Wilhelmi, A.E. (1965) Preparation of bovine, ovine and porcine prolactin. Endocrinology $77,150-154$.

Kwa, H.G., Van der Bent, E.M., Feltkamp, C.A., Runke, P.H. \& Bloemendal, H. (1965) Studies on hormones from the anterior pituitary gland. I. Identification and isolation of growth hormone and prolactin from the "granular" fraction of bovine pituitary. Biochem. Biophys. Acta 111, 447-465.

Lewis, U.J., Singh, R.N.P. \& Seavey, B.K. (1971) Human prolactin: isolation and some properties. Biochem. Biophys. Res. Commun. 44, 1169-1177.

Licht, P. \& Midgley, A.R., Jr (1976) In vitro binding of radioiodinated human follicle stimulating hormone to reptilian and avian gonads: radioligand studies with mammalian hormones. Biol. Reprod. 15, 195-205.

Maung, Z.W. \& Follett, B.K. (1977) Effects of chicken and ovine LH on androgen release and cyclic AMP production by isolated cells from the quail testis. Gen. comp. Endocr. 33, 242-253.

McNeilly, A.S. \& Andrews, P. (1974) Purification and characterization of caprine prolactin. $J$. Endocr. 60, 359-367.

McNeilly, A.S., Etches, R.J. \& Friesen, H.G. (1978) A heterologous radioimmunoassay for avian prolactin: application to the measurement of prolactin in the turkey. Acta endocr., Copenh. 89, 60-69.

Nicoll, C.S. \& Nichols, C.W., Jr (1971) Evolutionary biology of prolactins and somatotropins. I. Electrophoretic comparison of tetrapod prolactins. Gen. comp. Endocr. 17, 300-310.

Prunet, P., Djiane, J. \& Breton, B. (1977) Application of a radioreceptor assay for lactogenic activity to the detection of fish prolactin-like hormone. J. Endocr. 73, $391-392$.

Scanes, C.G. \& Follett, B.K. (1972) Fractionation and assay of chicken pituitary hormones. Br. Poult. Sci. 13, 603-610.

Scanes, C.G., Bolton, N.J. \& Chadwick, A. (1975) Purification and properties of an avian prolactin. Gen. comp. Endocr. 27, 371-379.

Shiu, R.P.C., Kelly, P.A. \& Friesen, H.G. (1973) Radioreceptor for prolactin and other lactogenic hormones. Science, N.Y. 180, 968-971.

Sluyer, M. \& Li, C.H. (1964) Studies of pituitary lactogenic hormone. XXIII. Isolation of the monomer of ovine prolactin. Archs Biochem. 104, 50-57.

Stockell-Hartree, A. \& Cunningham, F.J. (1969) Purification of chicken pituitary follicle-stimulating hormones and luteinizing hormone. J. Endocr. 43, 609-616.

Tsushima, T. \& Friesen, H.G. (1973) Radioreceptor assay for growth hormone. J. clin. Endocr. Metab. 37, 334-337.

Weber, K. \& Osborn, M. (1969) The reliability of molecular weight determinations by dodecyl sulfatepolyacrylamide gel electrophoresis. J. biol. Chem. 244, 4406-4412.

Workewych, J. \& Cheng, K.W. (1978) Development and application of a radioligand-receptor assay for thyrotropin. Gen. comp. Endocr. 35, 110-120. 